\title{
Accounting and Verification of Sustainable Enterprise Development Reporting
}

\author{
Margaryta SKRYPNYK, Nataliia RADIONOVA, Tetiana VLASIUK, \\ Svetlana BONDARENKO, And Olena GRYGOREVSKA
}

Kyiv National University of Technologies and Design, Ukraine

\author{
Correspondence should be addressed to: Margaryta Skrypnyk; lubanes@gmail.com \\ Received date:22 April 2019; Accepted date:16 July 2019; Published date: 5 September 2019 \\ Copyright (C) 2019. Margaryta SKRYPNYK, Nataliia RADIONOVA, Tetiana VLASIUK,Svetlana \\ BONDARENKO, And Olena GRYGOREVSKA. Distributed under Creative Commons CC-BY 4.0
}

\begin{abstract}
The mechanism for indicators formation of the social components of sustainable development reporting was improved through substantiation of accounting and nonaccounting information support and a development of an algorithm for their formation, which is the basis of a new information disclosure format for participants in socio-economic relations. The organizational provisions of the system of verification of sustainable development reporting were considered, and as a result: components of the verification system were substantiated (the company's obligations, principles, confirmation, requirements for the subject of verification); a model of the verification system organization was developed; and an algorithm for assessing and assigning a rating of verification was developed which is one of the key elements of the new mechanism for publicizing information about the economic activity of an enterprise. The methodological support of the verification procedure for sustainable development reporting was analyzed in terms of the assessment of the level of completeness of the subject of verification, the importance of requests from stakeholders and the effectiveness of socially responsible activities which involve the use of a set of analytical procedures and taking into account the information request of stakeholders on the sustainable development of the enterprise.
\end{abstract}

Keywords: social reporting, enterprise sustainable development, verification system, stakeholders, analytical procedures

\section{Introduction}

Sustainable development is the leading modern concept of the evolution of economic systems at various levels. Formed in the second half of the twentieth century, the situation of sustainable development was subject to modernization and systemic change and penetrated into various spheres of social and economic relations. At present, the provisions of sustainable development are not accepted

Cite this Article as: Margaryta SKRYPNYK, Nataliia RADIONOVA, Tetiana VLASIUK,Svetlana BONDARENKO, And Olena GRYGOREVSKA (2019)," Accounting and Verification of Sustainable Enterprise Development Reporting", IBIMA Business Review, Vol. 2019 (2019), Article ID 873407,

DOI: $10.5171 / 2019.873407$ 
and will be improved at the level both of theory and practice of economics. There is no doubt that the provisions of sustainable development have influenced the accounting system and were offered as fundamental in the development and implementation of modern concepts of its development in the world. The result of the influence of the provisions of sustainable development in the national accounting system is the introduction of a new mechanism for the disclosure of information about the activities of enterprises - sustainable development reporting. Its place in the modern accounting system is not defined, therefore, in some cases, these statements are beyond the scope of the accounting system, and in others - they are considered to be one of the types of financial statements. However, in all cases, sustainability reporting and the accounting system are interrelated. It is these interrelationships that have been little studied and require theoretical substantiation and the development of organizational and methodological provisions.

\section{Literature Survey}

The social aspects of business reveal the following issues (MARKET, R. Y. (2018), Hopkins, M. (2016), Wang, Q., Dou, J., \& Jia, S. (2016), Wang, H., Tong, L., Takeuchi, R., \& George, G. (2016)): employment results, employee relations in the company, security, staff training, diversity and equal opportunities, anti-discrimination, equal pay for work, government procurement and investment, freedom of association and association, right to bargain collectively, forced labor, child labor, local community, corruption, participation in public life, compliance with the norms and rules of health and safety, product labeling, customer privacy, marketing communications and other issues arising from specific activities.

Most recently, the concept of corporate social responsibility or business social responsibility has emerged (Grayson, D., \& Hodges, A. (2017)). According to this concept, everyone who is affected by the activities of the corporation (consumers, members of organizations for the protection of human rights and the environment, representatives of the local community, etc.) has the right to make business decisions, as well as the part of the profits (Drobyazko, S. (2018a)). It is assumed that business structures undertake responsibility for solving social problems, except for the requirements defined by law (Hilorme, T., Perevozova, I., Shpak, L., Mokhnenko, A. \& Korovchuk, Yu. (2019)). The socially responsible actions of corporations include: charity, employment, preservation of the environment, development of social programs to support the territories, delivery of additional (over and above the statutory) information about the quality of goods produced to the consumers; abstention from the manufacture of the products dangerous for consumers on their own initiative (Schwartz, M. S. (2017)).

The relevance of social responsibility of business is due to: the increasing of the role of human capital as a decisive factor in the competitiveness of a company and the increasing of the importance of intellectual factors of economic growth associated with human development (Drobyazko, S., Hryhoruk, I., Pavlova, H., Volchanska, L., \& Sergiychuk, S. (2019)).

\section{Methods}

In order to substantiate the theoretical provisions and prerequisites for the development of sustainable development reporting, the methods of theoretical generalization, analysis and synthesis are used. The formed actual base regarding the current state of sustainable development reporting and the use of international regulatory systems in sustainable development reporting are based on the application of observation methods, questionnaires and use of methodological techniques for data summarizing and grouping. The developed organizational and methodological provisions for the formation and accounting of sustainable development reporting are based on the use of induction and deduction methods, grouping, and theoretical generalization. Methods of modeling, analogy, abstraction, 
analysis, synthesis, induction and deduction were used to develop the organizational and methodological provisions for the verification of sustainable development reporting.

\section{Results}

Compared to the financial statements of the company, sustainable development reporting in terms of the social aspects of business meets the interests of various user groups and ensures the growth of the influence of the positive nature of entrepreneurial activity on society and socio-economic relations.

The social category of sustainability development reporting reveals a wide range of issues related to relations between company and society, which are expressed through human rights regulation, labor relations, social assistance and the company responsibility to various categories of subjects (in particular, the government, employees and customers (suppliers and buyers)).

Table 1: Classification of expenses of social activities with their division into accounting objects in the context of indicators of sustainable development reporting

\begin{tabular}{|c|c|}
\hline $\begin{array}{l}\text { Reporting } \\
\text { indicators }\end{array}$ & Expenses with their division into accounting objects \\
\hline G4-LA1 & expenses associated with the employment: employee search expenses \\
\hline G4-LA2 & $\begin{array}{l}\text { expenses associated with payments to employees: labor costs for full-time } \\
\text { employees; labor costs for part-time employees; labor costs for temporary } \\
\text { employees }\end{array}$ \\
\hline G4-LA13 & $\begin{array}{l}\text { expenses associated with payments to employees: labor costs for male } \\
\text { employees; labor costs for female employees }\end{array}$ \\
\hline G4-LA14 & $\begin{array}{l}\text { expenses associated with conducting a comprehensive audit of the practice of } \\
\text { labor relations with suppliers: labor costs for the personnel performing the } \\
\text { assessment procedures; material costs; other types of expenses }\end{array}$ \\
\hline G4-HR1 & $\begin{array}{l}\text { expenses associated with ensuring human rights: expenses for programs } \\
\text { implemented to evaluate existing treaties containing provisions on ensuring } \\
\text { human rights; expenses associated with the preparation and implementation of } \\
\text { investment contracts containing provisions on ensuring human rights }\end{array}$ \\
\hline $\begin{array}{l}\text { G4-HR5, } \\
\text { G4-HR6 }\end{array}$ & $\begin{array}{l}\text { expenses for activities aimed at the effective overcoming of child and forced } \\
\text { labor: material costs; labor costs of personnel working in the field of counseling } \\
\text { and interpretation of employment issues; other expenses }\end{array}$ \\
\hline G4-HR7 & \multirow{2}{*}{$\begin{array}{l}\text { expenses associated with the training of employees of the company: costs of } \\
\text { training within the company (on its own); costs of training outside the } \\
\text { company (with the involvement of outside organizations) }\end{array}$} \\
\hline G4-S04 & \\
\hline G4-S06 & $\begin{array}{l}\text { expenses associated with the implementation of state policy: expenses for the } \\
\text { election campaign of candidates for political structures of employees of the } \\
\text { company; expenses for the election campaign of candidates for political } \\
\text { structures of citizens who do not work in the company }\end{array}$ \\
\hline G4-S08 & \multirow{3}{*}{$\begin{array}{l}\text { expenses associated with the responsibility of the company: fines received with } \\
\text { damages in monetary terms; fines received with damages in non-monetary } \\
\text { terms; received fines in the form of deprivation of individual rights }\end{array}$} \\
\hline G4-PR4 & \\
\hline G4-PR9 & \\
\hline G4-S010 & $\begin{array}{l}\text { expenses associated with the responsibility of the company: expenses for the } \\
\text { assessment of the suppliers impact on society; expenses associated with } \\
\text { measures to reduce or prevent the occurrence of a negative impact on society } \\
\text { upon products sale }\end{array}$ \\
\hline G4-PR3 & $\begin{array}{l}\text { expenses associated with the responsibility of the company: expenses for } \\
\text { disposal of products; expenses for product labeling; expenses for reducing the } \\
\text { impact of products on society }\end{array}$ \\
\hline
\end{tabular}



satisfaction of claims in monetary terms; expenses for satisfaction of claims in non-monetary terms

At the present stage of development of the accounting system, there is no fixed list of the above mentioned expenses as categories of accounting objects at the legislative level, except for the first three categories of expenses related to employment, payments and training of employees. Therefore, accounting support of sustainable development reporting in terms of the social component requires improving and resolving issues on the formation of a methodological approach that will ensure the accuracy, completeness and timeliness of information in the non-financial reports of business entities.

In our opinion, it is possible to offer such a list of objects of accounting for social activities of the company, which are distinguished at the request of sustainable development reporting and based on the analysis of scientific literature and the analyzed non-financial reports of business entities:

Social assets: labeled finished products; raw materials and materials by sources of origin which affect society.

Social responsibility: to the state (payment of taxes, fines for violation of the law), to customers (suppliers, buyers), to employees (payment of salary, employment creation, training and advanced training).

Social expenses: expenses associated with the employment; expenses associated with conducting a comprehensive audit of the practice of labor relations with suppliers; expenses associated with ensuring human rights; expenses for activities aimed at the effective overcoming of child and forced labor; expenses associated with the implementation of state policy; and expenses associated with the responsibility of the company.

Social income: income in the form of interest of the provision of loans to employees, lending and other forms of financing; and income from the disposal of labeled finished products.
The identified objects of accounting are characterized by the extent to which social relations are integrated into the economic system of the company. Therefore, as far as the list and essence of each of the objects will be accurately determined, this will affect the information value of the indicators of sustainable development reporting.

Regarding the expenses associated with the social responsibility, according to the results of the study, we describe the following types of them: expenses associated with the falsification of reporting, discrimination in the workplace, corruption, etc.; expenses associated with the measures to reduce or prevent the occurrence of a negative impact on society upon the sale of products; expenses for disposal of products; expenses for product labeling; expenses for reducing the impact of products on society; and expenses for satisfaction of claims in monetary and nonmonetary terms.

Thus, on the basis of the conducted accounting study, it can be concluded that for sustainable development reporting it is necessary to provide for the preparation of internal (management) reporting of the company which will ensure the disclosure of complete information in order to manage the company and make decisions by interested user groups based on non-financial reporting. It is not advisable to provide in the financial reporting the disclosure of those indicators that will overload the informative fullness of reports.

The proposed form of internal (management) reporting is necessary to provide information to a group of responsible persons for drawing up sustainable development reporting in terms of the company social activities. The proposals offered provide: disclosure of information about positive and negative aspects of social activity (after all, they take into account both the company investment in human capital and the types of complaints received from consumers and other customers); assessment of the social activity of the company by interested user groups; obtaining of operational information and for a 
certain period for making relevant decisions by management; and comparative assessments of social activities since the reporting is compiled for a specific reporting period in comparison with the previous similar one.

The introduction of social responsibility principles in the activities of any company is an important period in which a number of procedures for assessing and correcting sustainable development reporting are carried out which determine the further level of efficiency of management processes of a socially responsible company and specializes in the system of verification for implementing social responsibility and sustainable development reporting sustainable development. The verification of the facts of economic life on the reliability of their recording becomes an important factor in improving the reputation of a business entity (Hilorme, T., Shurpenkova, R., KundryaVysotska, O., Sarakhman, O., \& Lyzunova, O. (2019), ) Hilorme, T., Zamazii, O., Judina, O., Korolenko, R. \& Melnikova, Yu. (2019).

The purpose of verification of sustainable development reporting is to check the reliability of its quantitative and qualitative data and to assess the system for collecting data indicators which confirms the seriousness of understanding by the company of its own corporate social responsibility.

The level of verification will increase as information is refined and systems for sustainable development reporting are improved (Drobyazko, S. (2018b)).

The materiality principle requires that the company should include in the verification report information on materiality indicators that are necessary for interested parties to implement valid conclusions, make decisions and take management activities.

The information is material if its absence or distortion may affect decision-making of interested parties (Singh, B. J. R., \& Kaur, M. P. (2016)).

Principle of completeness of information: this principle requires that the indicators of financial stability be assessed, both for the company itself and for the structural units for which it bears management and legal responsibility (Rao, K., \& Tilt, C. (2016), Moon, J., \& Knudsen, J. S. (2018, July)).

The subject of verification should indicate significant shortcomings in the assessment of financial sustainability indicators given in the reporting, which is verified.

The subject of verification should also discuss with the company the existing shortcomings in terms of completeness of information, suggesting to solve this problem or recording the fact of incomplete information in the report.

Principle of response: the principle requires that the subject of verification assesses the level of company response to inquiries and comments of stakeholders and its recording degree in sustainable development reporting (Suliman, A. M., Al-Khatib, H. T., \& Thomas, S. E. (2016), Lins, K. V., Servaes, H., \& Tamayo, A. (2017)).

The principle of response requires that the reporting company demonstrates in the report what it is going to do in response to comments or requests from interested parties, and also provides relevant examples. This principle does not require the company to clearly and consistently respond to requests and comments from interested parties.

The certificate of conformity should reflect the accuracy of the reports and indicators that provide the necessary information.

Requirements to the subject of verification: the external or internal subjects of verification of corporate social responsibility must meet the following requirements:

1. Reliability and independence of the subject of verification (the subject of verification must be independent and impartial in relation to the interested parties and the company in which reporting is being verified).

The subject of verification must openly declare the presence of interests of any kind that adversely affect the degree of such independence and impartiality. In order to ensure its independence, the subject of verification can rely on a number of existing ethical codes and mechanisms depending on their professional field of activity, 
institutional affiliation or geographic location. Given this, the subject of verification should, for each verification work task, make a public declaration of independence, which contains: a confirmation of independence from the company; a description of the policy pursued in the event of a conflict of interest; a description of any past, current or potential financial or commercial relationship between the subject of verification and the business entity in which reporting is verified, such as the provision of services on a fee-based basis (eg, consultations, research), participation in management, or a share in equity. This rule applies to both legal and individual persons performing the verification task.

2. Impartiality of the subject of verification. Impartiality is defined as the ability and willingness of the subject of verification to perform a coordinated work task for verification so that the information obtained in the verification process and his professional judgment or statements are not affected by relationships with interested parties (including shareholders).

3. Individual competence: the subject of verification and a business entity, in which reporting is verified, must ensure the appropriate competence of persons involved in each specific verification process. The business entity should require the subject of verification to be willing to provide information to the interested parties about the competence of those involved in the verification process. The competence of persons involved in the verification of reporting should include the following elements:

1. Professional qualifications, for example, the ability to work with quantitative data, training on certain aspects of verification, knowledge of specific aspects of activities and their consequences (for example, environmental, human rights);

2. The experience of the verification process, in particular, the experience of verification in the socio-ethical, environmental, economic and financial spheres;
3. The scope of professional knowledge and experience of the main parameters of the information provided to the interested parties.

4. Organizational competence: the subjects of verification, which include leading verification specialists, must confirm the corresponding institutional competence to which belong: an adequate verification control to ensure that verification is carried out at the highest level without compromising on quality due to commercial interests or lack of competence; an adequate understanding of the legal aspects of the process of verification and insurance against professional harm; an existing infrastructure to ensure the verification process, as well as the conditions for safe long-term storage of materials provided for verification.

Individual entrepreneurs who provide verification services should, likewise, comply with the requirements described above.

Given the above, let's consider the features of the organization of the system of verification of corporate social reporting conducted by the internal audit service.

At this stage, auditors should obtain reliable evidence on the level of study of issues related to the interaction with stakeholders.

An interested parties prefer interactions and may require changes in the following ways: working on establishment of the formal legal and contractual rights and obligations; participation in legally permitted protests and information events; cooperation with representative organizations, legitimacy of representative functions which are based on their reputation; participation in representative organizations with authorized powers; development and implementation of benchmarks and indicators; support and participation in election campaigns; and the use of complex lobbying tools.

The recommendations of the auditors are the need to understand the identified shortcomings in the management of the company and the development of leveling procedures which should be reflected in the policy of the company on the instructions of 
the personnel department, recruitment department and sales department. Auditors point out that ignoring such problems significantly affects relationships with stakeholders, creates a negative perception of the company's image and may affect the sustainability of its development.

\section{Discussion}

The process of assessment and verification rating assignment consists of six interrelated stages: conclusion of an agreement on the provision of rating services; information providing for conducting a rating study; analysis of the provided information, rating study conducting; formation of the preliminary conclusion on the rating; customer informing about the results of assessment and rating; execution of the rating report and distribution of information about the rating in the media or signing of a nondisclosure agreement and the results of the assessment are transferred to the customer.

At the first stage, an agreement is concluded for carrying out verification services, which determines the rights and obligations of the subject of verification and the subject being verified, the timing of the verification process, and the special conditions that may occur during verification and do not contradict the requirements of corporate social responsibility verification standards. If verification is carried out by the internal control service, then at this level it is enough to execute internal regulatory verification documents. At the third stage, the analysis of information provided by the company in which reporting is verified, rating studies, and implementation of current findings are carried out.

Based on the rating study, conclusions are made regarding the sufficiency and completeness of the information provided for the verification of corporate social reporting. If this information is not enough, the subject of verification requests additional information for verification.

If the received information is sufficient for assigning a certain rating, the fourth stage of verification takes place - the formation of a preliminary general conclusion and the assignment of a rating to a business entity in which reporting has been checked for verification.

At the next stage, the customer is informed of the results of assessment and rating assignment in accordance with the volume and quality of the information obtained for verification.

The final stage is the execution of the rating report, in case the customer agrees on the results of verification disseminating the results of verification to the media, which is one of the responsibilities of the subject of verification.

If the company does not agree with the conclusions of the subject of verification or it does not like the obtained level of verification, then an agreement on a nondisclosure of information is signed between them and the results of the assessment are transferred to the customer. Repeated verification in this case is not performed.

If we talk about the levels of verification of corporate social responsibility, then they are separately established by the subjects of verification in accordance with the chosen methodology and organization of the verification process. Based on the analysis of the use in practice by the subjects of verification of various levels of verification, the main existing approaches are summarized as well as the proposed author's scale of verification (Table 2).

The proposed list of levels of verification is not exhaustive and can be either expanded or integrated according to the decision of the subject of verification. 
Table 2: Levels of verification of corporate social responsibility

\begin{tabular}{|c|l|}
\hline $\begin{array}{c}\text { Verification } \\
\text { level }\end{array}$ & \multicolumn{1}{c|}{ Level characteristics } \\
\hline AAA & the highest level of corporate social responsibility \\
\hline AA & very high level of corporate social responsibility \\
\hline A & high level of corporate social responsibility \\
\hline BBB & acceptable level of corporate social responsibility \\
\hline BB & adequate level of corporate social responsibility \\
\hline B & satisfactory level of corporate social responsibility \\
\hline C & low / unsatisfactory level of corporate social responsibility \\
\hline NR & rating is not assigned or withdrawn \\
\hline
\end{tabular}

Thus, we have analyzed the features of the verification process of corporate social reporting and the requirements of this process. The features of the organization of the internal audit system as the main internal subject of verification are established, the main audit methodologies used in practice and in the verification system are defined.

Describing the features of the audit verification of corporate social reporting, it is important to note that there must be special requirements for the selection of a group of auditors which are determined by a wide range of diagnostics of social responsibility.

\section{Conclusion}

As a part of the study of the social component of sustainable development reporting, the mechanism for recording its indicators were improved. Improvement of reporting as the basis for information support of the process of formation of indicators of the social aspects of sustainable development reporting took place at the proposed form of an internal report (Report on social activities), which is reasonably prepared to summarize the social aspects of business entities. This allows the assessment of social activities on positive and negative impacts on society, labor relations, human rights, as well as obtaining reliable and timely information for the formation of indicators of sustainable development reporting. The proposed procedure for carrying out the procedure for the reporting of sustainable development verification can be adjusted in accordance with the main strategic indicators of the company development, current policies, as well as the guidelines approved by the social reporting indicators.

On the basis of the proposed mechanism for sustainable development reporting, the problem issues of accounting support were identified, according to which the study task was set and proposals were made for their solution. In particular, the types of expenses of social activity were determined, which allowed identifying objects of social accounting (social assets, social responsibility, social income and social expenses). According to the above accounting objects, the issues of their documentation, recording on synthetic and analytical accounts and in financial statements are disclosed. As a result, it was proposed to use the social activity report of the company as a form of the company internal reporting. The proposals presented in the study allow forming highquality, reliable and complete information in the sustainable development reporting by the social component.

Taking into account the requirements of current legislation and the requirements of international verification standards, a methodical approach has been proposed for the procedure of carrying out the procedure of verification of sustainable development reporting which consists of the following stages: assessment of the level of competence of the subject of verification; and assessment of the importance of stakeholder requests and assessment of the effectiveness of socially responsible activities. 
Prospects for further study is to assess the quality of the audit of sustainable development reporting by assessing the level of competence of potential candidates for the internal audit service, and determining the level of priority of the expressed interests of stakeholders.

\section{References}

1. Drobyazko, S. (2018a). Accounting management of enterprises' own of in the conditions of legislative changes. Economics and Finance, 10, 4-11. URL: http://ecofin.at.ua/maket_ehkonomika_i_fi nansy_06_2018.pdf

2. Drobyazko, S. (2018b). Features of tourism services accounting structuring in the information-oriented society. Economics and Finance, Volume, 6, 44-49. URL:

http://ecofin.at.ua/maket_ehkonomika_i_fi nansy_10_2018.pdf

3. Drobyazko, S., Hryhoruk, I., Pavlova, H., Volchanska, L., \& Sergiychuk, S. (2019). Entrepreneurship Innovation Model for Telecommunications Enterprises. Volume 22, Issue 2, 2019. URL: https://www.abacademies.org/articles/en trepreneurship-innovation-model-fortelecommunications-enterprises-8097.html

4. Grayson, D., \& Hodges, A. (2017). Corporate social opportunity!: Seven steps to make corporate social responsibility work for your business. Routledge. URL: https://www.taylorfrancis.com/books/97 81351948418

5. Hilorme, T., Perevozova, I., Shpak, L., Mokhnenko, A. \& Korovchuk, Yu. (2019). Human Capital Cost Accounting in the Company Management System. Academy of Accounting and Financial Studies Journal. Volume 23, Special Issue 2, 2019. URL: https://www.abacademies.org/articles/Hu man-Capital-Cost-Accounting-in-theCompany-Management-System-15282635-23-SI-2-415.pdf

6. Hilorme, T., Shurpenkova, R., Kundrya-Vysotska, O., Sarakhman, 0., \& Lyzunova, O. (2019). Model of energy saving forecasting in entrepreneurship. Journal of Entrepreneurship Education. Volume 22, Special Issue 1S. URL: https://www.abacademies.org/articles/m odel-of-energy-saving-forecasting-inentrepreneurship-7994.html

7. Hilorme, T., Zamazii, O., Judina, O., Korolenko, R. \& Melnikova, Yu. (2019). Formation of risk mitigating strategies for the implementation of projects of energy saving technologies. Academy of Strategic Management Journal. Volume 18, Issue 3. URL:

https://www.abacademies.org/articles/Fo rmation-of-risk-mitigating-strategies-forthe-implementation-of-projects-19396104-18-3-364.pdf

8. Hopkins, M. (2016). The planetary bargain: corporate social responsibility comes of age. Springer. URL: https://books.google.com.ua/books?hl=uk \&lr=\&id=XUC_DAAAQBAJ\&oi=fnd\&pg=PR1 $0 \& \mathrm{dq}=$ Corporate + Social + Responsibility $+\&$ ots=rixUKqj6VR\&sig=3JQghtDBWozhJaRb4 cEXn2E6r0U\&redir_esc=y\#v=onepage \&q= Corporate\%20Social\%20Responsibility\&f= false

9. Lins, K. V., Servaes, H., \& Tamayo, A. (2017). Social capital, trust, and firm performance: The value of corporate social responsibility during the financial crisis. The Journal of Finance, 72(4), 17851824. https://onlinelibrary.wiley.com/doi/full/1 $0.1111 /$ jofi.12505

10. MARKET, R.Y. (2018). Corporate social responsibility. URL: http://globelink.ca/wpcontent/uploads/2018/05/CorporateSocial-Responsibility-2018.pdf

11. Moon, J., \& Knudsen, J. S. (2018, July). Corporate social responsibility and government. In Academy of Management Proceedings (Vol. 2018, No. 1, p. 12777). Briarcliff Manor, NY 10510: Academy of Management. URL: https://journals.aom.org/doi/abs/10.5465 /AMBPP.2018.12777abstract

12. Rao, K., \& Tilt, C. (2016). Board composition and corporate social 
responsibility: The role of diversity, gender, strategy and decision making. Journal of Business Ethics, 138(2), 327-347. URL: https://link.springer.com/article/10.1007 /s10551-015-2613-5

13. Schwartz, M. S. (2017). Corporate social responsibility. Routledge. URL: https://www.taylorfrancis.com/books/97 81351948418

14. Singh, B. J. R., \& Kaur, M. P. (2016). Corporate social responsibility in India. International Journal of Higher Education Research \& Development,1(1). URL:

https://www.researchgate.net/profile/Ank ur_Rastogi6/publication/325895115_A_CR ITICAL_ANALYSIS_OF_ECOMMERCE_COMPANIES_IN_INDIA_IN_TH E_CONTEXT_OF_THEIR_POPULARITY/links /5b2b4aa2aca27209f3797eed/ACRITICAL-ANALYSIS-OF-E-COMMERCECOMPANIES-IN-INDIA-IN-THE-CONTEXTOF-THEIR-POPULARITY.pdf\#page $=338$

15. Suliman, A. M., Al-Khatib, H. T., \& Thomas, S. E. (2016). Corporate social responsibility. Corporate Social Performance: Reflecting on the Past and Investing in the Future, 15. URL: https://books.google.com.ua/books?hl=uk $\& \mathrm{l}=\& \mathrm{id}=$ gcoDwAAQBAJ\&oi=fnd \&pg=PA1 $5 \& \mathrm{dq}=$ Corporate + Social+Responsibility $+\&$ ots=RJCIqVWx03\&sig=9-

YLfrqaSOcpLiKZ1iWKYqgIHrU\&redir_esc= $\mathrm{y} \# \mathrm{v}=$ onepage $\& \mathrm{q}=$ Corporate $\% 20$ Social $\% 20$ Responsibility\&f=false

16. Wang, H., Tong, L., Takeuchi, R., \& George, G. (2016). Corporate social responsibility: An overview and new research directions: Thematic issue on corporate social responsibility. URL: https://journals.aom.org/doi/abs/10.5465 /amj.2016.5001

17. Wang, Q., Dou, J., \& Jia, S. (2016). A meta-analytic review of corporate social responsibility and corporate financial performance: The moderating effect of contextual factors. Business \& Society, 55(8), 1083-1121. URL: https://journals.sagepub.com/doi/abs/10. 1177/0007650315584317 